\title{
Lament for a health care system
}

Published at www.cmaj.ca on June 20, 2005. Revised on June 29, 2005.

T he Supreme Court of Canada's decision ${ }^{1}$ to disallow Quebec's prohibition of private insurance to cover medically necessary services available through the public system has been received by some as a long-overdue vindication of the right of individuals to timely access to health care, and by others as a life-threatening body blow to medicare. In effect, the Supreme Court has handed our health care system a failing grade. No matter the "fix for a generation" promised by the $\$ 41$ billion Health Care Accord; no matter the specific intents of the Wait Time Alliance; no matter the Romanow Commission's reaffirmation of publicly administered health care as a defining national value. The system has failed to deliver; Charter rights to life and security of the person have been compromised; the people of Canada have waited long enough for cataract surgery, for diagnostic procedures, for refurbished hips and knees - and for radical surgery on medicare. So says a narrow majority of our highest court.

Where do we go from here? The already cyanotic government might hold its breath waiting for further Charter challenges - as will surely arise - to produce a contradictory judgment. The provinces might be galvanized to find "innovative solutions" to long waiting lists and other systemic ailments. (What, have they lacked sufficient motivation before?) We may discover that the sky does not fall and that the constitutional legitimization of what is already legal in 4 provinces (Saskatchewan, New Brunswick, Nova Scotia and Newfoundland) will make only a small dent on public provision. (Provided that other deterrents against overgrowth in the private sector are not made illegal, too.) We may learn, as Colleen Flood and Terrence Sullivan point out (see page 142) ${ }^{2}$ that waiting lists are longer, not shorter, in a hybrid system. And it may well be that most Canadians, skeptical of the profit motive, will stick with the devil they know: an imperfect public system that for the most part delivers well on urgent and intensive care.

How did we get to this unexpected juncture? Some commentators point to resistance to reform within organized medicine; others blame a lack of political leadership and will, citing among other things the inconsistent enforcement of the Canada Health Act (e.g., Quebec's disregard for portability is perhaps not immaterial to this case). Others have pointed to socioeconomic change, which has created a stronger voice among the affluent, who identify less and less with the poor. Or perhaps we have been brought here by the ascendency of individualism, by which our long-standing commitment to the common weal in matters of health is now hoist by the petard of Charter rights. The spirit of fairness, reasonableness and public good that inspired the Canada Health Act has been trumped by the letter of the Charter.

The Canada Health Act does not guarantee in any direct manner our right to health care; rather, it expresses, upholds and facilitates our societal commitment to equal and reasonable access to those services that are publicly provided, without regard to insurability or ability to pay. Nowhere is the right to health care directly enshrined. We do not have a patients' bill of rights, a health care charter, a written guarantee that when we are sick the state will make us well. And yet, this abstract right of mythic stature in our national psyche is protected through the conditions under which federal monies are assigned to the provinces for the provision of health services: portability, accessibility (which must imply timeliness), public administration, universality and comprehensiveness. It is protected by provincial prohibitions against direct and extra billing, private insurance for public services (until now) and for-profit hospitals. The shining ideal of equality in health care access has been protected to perhaps a miraculous degree by complex, pragmatic and provincially variable checks on the growth of the private system. It is this delicate balance that the Supreme Court decision has made all the more unstable by enhancing the claim of the affluent to a fast-track to care.

What is certain is that without practical judiciary guidance, or the possibility of same, on what constitutes "unreasonable" delays in treatment, the door is now open to wasteful and time-consuming legal claims and to more court challenges to the limits of privatization. We respectfully submit that the time and effort these will entail would be better spent on implementing solutions - such as centralized waiting lists - that will not only work, but will work equally well for all. — CMAf

\section{References}

1. Chaoulliv. Quebec (Attorney General). 2005 SCC 35

2. Flood CM, Sullivan T. Supreme disagreement: The highest court affirms an empty right. CMA7 2005;173(2):142-3. 